\title{
Role of ilizarov in complex and post-traumatic disorders in the inferior extremity - reconstruction versus amputation
}

\section{Introduction}

Complex open fractures or posttraumatic conditions (aseptic and infected nonunion) of the inferior extremity is a big challenge for the Orthopaedic and Reconstructive surgeon who often need to choose if a reconstruction procedure is possible rather than an amputation. The Ilizarov method of bone resection and lengthening helps to stabilize fracture and to rebuild bone, muscle and skin defect. The surgical procedure starts with a surgical toileting of damaged soft tissue and necrotic bone followed by bone resection and lengthening by Ilizarov technique. ${ }^{1-4}$

\section{Patients and Method}

From 1995 to 2017 we have treated 186 patients with leg open fractures or post-traumatic conditions with huge bone, muscle and skin loss.122 were males and 64 were females, mean age was 52 years.Results

Figure 1 at minimum follow up of 3years, functional results have been excellent in 170 cases, sufficient in 16 cases. Minimum healing time has been 8 months. We had 8 cases of deep infections in the resection site or in the proximal osteotomy site; no cases of nonunion or residual axis deformity was observed. In 12 cases we observed ankle stiffness. Bone defect restored by gradual lengthening. We observed also a progressive recovering of skin and soft tissue defect. ${ }^{5-9}$
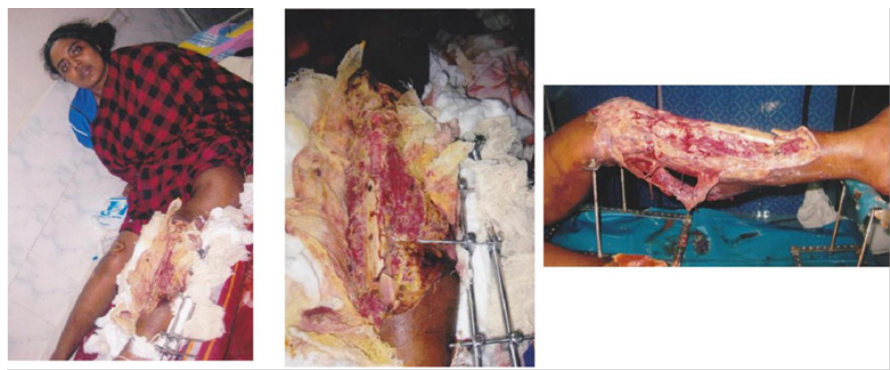

Figure I 24yrs. Old female - MVC - devastating infected wound GIIIB fracture femur, tibia/fibula with uni axial fixator in situ.

\section{Discussion}

Ilizarov technique of bone resection and lengthening is a treatment option to save a limb from amputation in complex inferior limb fractures or posttraumatic conditions. A good evaluation of patient psychology needs to be assessed to propose this long-term treatment. However, if patients are motivated enough in most cases surgeon can reconstruct the limb offering a good quality of function. The key of success lies in a careful plan of the case, the choice of the most stable implant, doing a good and extensive debridement, a meticulous intelligent follow up, a strong psychological support for these patients long term treatment and to be balanced with the need of patient to come back to work as soon as possible since also an amputation is not

\section{Volume 10 Issue 5 - 2018}

\section{Bari MM,' Shahidul Islam, ${ }^{2}$ Mahfuzer Rahman ${ }^{3}$ 'Chief Consultant Bari-llizarov Orthopaedic Centre,Visiting and Honored Professor of Russian llizarov Scientific Centre, Kurgan ${ }^{2}$ Bari-llizarov Orthopaedic Centre, Bangladesh \\ ${ }^{3}$ Consultant, Bari-llizarov Orthopaedic Centre, Bangladesh}

Correspondence: Bari MM, Chief Consultant Bari-llizarov Orthopaedic Centre,Visiting and Honored Professor of Russian Ilizarov Scientific Centre, Kurgan, Bangladesh, Email bari.ilizarov3।@gmail.com

\section{Received: September 22, 2018 | Published: September 24,} 2018

a surgery without complications and in some cases a patient with an amputation would not be taken back to work in certain type of jobs (Figure 2) (Figure 3). 1,2,4,8,9
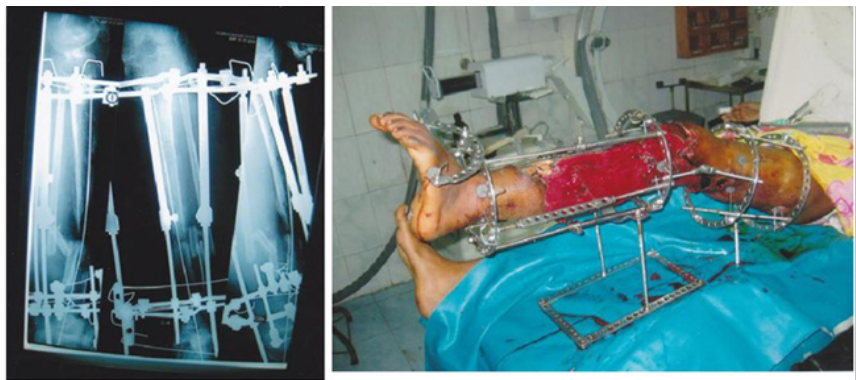

Figure 2 llizarov in It. tibia/fibula and femur.
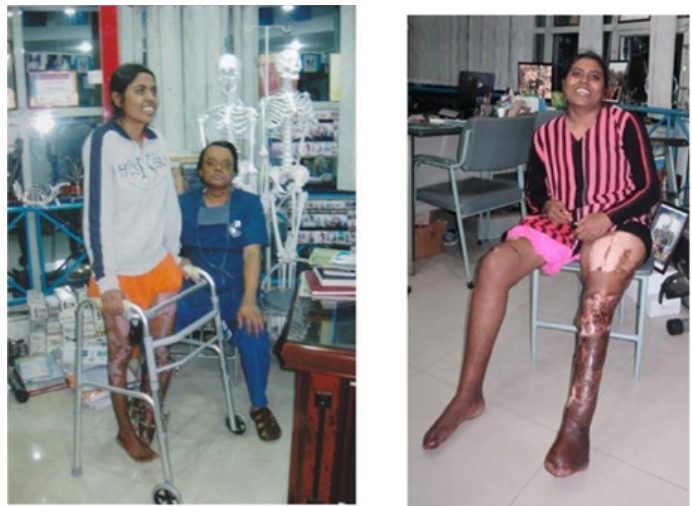

Figure 3 Follow up after lyear and 7months.

\section{Conclusion}

The Ilizarov technique for the treatment of complex and posttraumatic disorders of diaphyseal long bones are effective and 
offer many advantages. One of the greater advantages of this technique is that it allows for the simultaneous treatment of bone loss, infection, nonunion. Deformity and problems of soft tissues at the same time. In our all cases complications were not severe and did not affect the results.

\section{Acknowledgements}

None.

\section{Conflict of interest}

Author declares that there is no conflict of interest.

\section{References}

1. Bari MM. A color atlas of limb lengthening, surgical reconstruction and deformity correction by Ilizarov technique. 2013:66-74.

2. Bari MM. Correction of leg deformities and restoration of function of leg bones by Ilizarov technique. 2014:62-81.
3. Alonso JE, Regazzoni P. The use of Ilizarov concept with the AO/ASIF tubular fixator in the treatment of segmental defects. Orthop Clin North Am. 1990;21(4):655-665.

4. Ilizarov GA. Basic old transosseous and distraction osteosynyhesis. Orthop Traumatol Protez. 1971;32(11):7-15.

5. Kalnberg BK. Compression-distraction apparatus and system of stability. Riga, Latvia; 1981.

6. Golyakhovsky V, Frankel V, Victor Ferrara H, et al. Operative manual of Ilizarov technique. Maryland: Mosby publishers; 1993. 231p.

7. Paley D. Problems, obstacles and complications of limb lengthening by the Ilizarov technique. Clin Orthop. 1990;(250):81-104.

8. Paley D, Catagni MA, Argnani, et al. Ilizarov treatment of non-unions with bone loss. Clin Orthop. 1989;241:146-165.

9. Ilizarov GA. Transosseous osteosynthesis. Theoretical and clinical aspects of the regeneration and growth of tissues. 1st ed. New York: Springer- Verlog Berlin Heidelber; 1992. p. 1-800. 